\title{
'A comparison between the environmental damages of two axial air compressors manufactured by the firm FINI COMPRESSORI'
}

\author{
Paolo Neri ${ }^{* a}$, Giuseppe Bernardi ${ }^{\mathrm{c}}$, Patrizia Buttol ${ }^{\mathrm{a}}$, Giovanni Naldi ${ }^{\mathrm{c}}$, Miroslav Saric ${ }^{\mathrm{d}}$, \\ Giovanni Tani ${ }^{\mathrm{b}}$ \\ ${ }^{a}$ Italian National Agency for New Technologies, Energy and Environment, Bologna \\ ${ }^{\mathrm{b}}$ Department of Mechanics and Industrial Technology of Florence University \\ ${ }^{c}$ Department of Mechanical Constructions Engineering of Bologna University \\ ${ }^{\mathrm{d}}$ Technical Office of the firm FINI COMPRESSORI, Zola Predosa (Bologna)
}

\begin{abstract}
This study was performed jointly by ENEA (Italian National Agency for New Technologies, Energy and Environment), Bologna and Florence Universities and the firm FINI COMPRESSORI. A comparison is carried out between the environmental damages of two models (MK10 and MK94) of air axial compressors manufactured by FINI COMPRESSORI, with a volume of intaken air of $226 \mathrm{l} / \mathrm{min}$, a power of $1.8 \mathrm{~kW}$ and a maximum pressure of $10 \mathrm{bar}$. The comparison is obtained by using LCA calculated by SimaPro 3.1 code and two methods: Eco-indicator 95 and a new method obtained by adding to the Eco-indicator 95 method other damage categories such as some raw material depletion, solid and energy. The system boundaries include raw material extraction and the end of life of the components and some special tools for manufacturing such as dies, moulds and shells. All metallic materials have the recycling as waste scenario. For LCA study we have considered the three components crankshaft, crankcase and valve plate for both the models, the air cooling conveyor for the MK94 and the surplus of consumed energy for the MK10. The conveyor decreases the temperature of air and therefore increases the compressor efficiency and reduces the electrical energy consumption during the use.

From the LCA results, we can conclude that the introduction of the conveyor reduces the damage of MK10 model of $114.07 \mathrm{mPt}$ and that the other modifications of the design increase the damage of MK10 model of $11 \mathrm{mPt}$.

The damage of air compressor can be diminished by reusing crankshaft and crankcase. A design modification of the blades of the ventilator is proposed to avoid the conveyor.
\end{abstract}

Key words: Life Cycle Assessment, Air compressor, Ecodesign, Eco-indicator 95, Ventilator

\section{INTRODUCTION}

This study was performed jointly by ENEA, Bologna and Florence University and the firm FINI COMPRESSORI ${ }^{1,4}$. We have compared the environmental damage of some component of two air compressors manufactured by FINI COMPRESSORI. We have considered the model MK10 and MK94 because they have the following very similar characteristics:

- the electric power: $1.8 \mathrm{~kW}$

- The maximum pressure: $10 \mathrm{bar}$

- The ram average velocity: $1.6 \mathrm{~m} / \mathrm{s}$

- Swept volume: $200 \mathrm{~cm}^{3}$ for MK10 and $215 \mathrm{~cm}^{3}$ for MK94

- $\quad$ Volume of the air sucked up: 226 1/min for MK10 and 268 1/min for MK94.

The model MK10 was designed in the 1975 and the model MK94 twenty years after.

\section{DEFINITION OF AIMS AND BOUNDARIES OF THE STUDY.}

The study has the goal of evaluating the ecodesign criteria used in the most recent MK94 compressor model. The results of this study will be used in the design of a new compressor model.

The system to be studied is the production of a force or a moment by using compressed air.

The functional unit of the two LCA applied to the two models is for both models the group of the following components: crankshaft, valve-plate and crankcase. In the functional unit of the MK94 model also the conveyor is considered. The cooling air conveyor carries the air on the pumping set and cools particularly the valve-plate and the

* Correspondence: Email: neri@bologna.enea.it; Telephone: 3951 6098518; Fax: 39516098594 
head. The temperature of the compressed air decreases, its volume increases and therefore the quantity of the electric energy for a unit of air volume used during the life of MK94 model is lower than the one used by MK10 model. In the functional unit of the MK10 model even the difference between the electric energy used by the two compressors is considered. Fig. 1 shows the studied components.

Fig.1 The studied components.
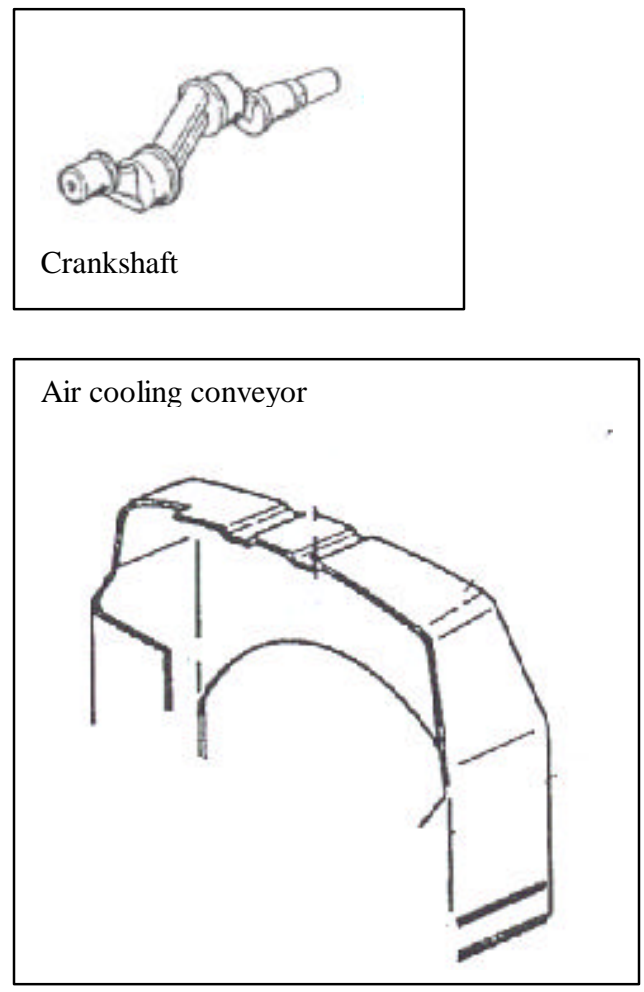
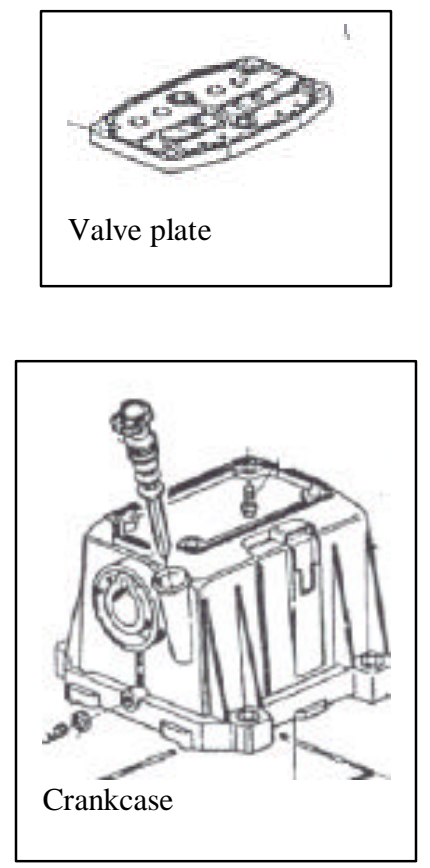

The boundaries of the study include the extraction of the minerals and fuels and the end of life of the components of compressor. The use of the compressors is considered in the difference between the electric energies used by two compressors. In the LCA study we have considered even the manufacturing processes, the thermal treatments, the transports and the end of life of the dies used for producing the die - casting of aluminium, for the forging of the steel and for the casting of cast iron and aluminium.

The data have the following characteristics:

- we have used the data of the database of the code SimaPro3.1. Some new materials and processes had been created by using data of literature and of manufacturing firms.

- The methods used are reproducible but do not consider all the emitted substances.

- The databases are IDEMAT 96 and PRé.

The LCA study is performed by using SimaPro $3.1^{2}$ code and the method Eco - indicator 95 Europe g. For comparison we have used a second method obtained by modifying Eco - indicator 95 Europe $\mathrm{g}$ by the introduction as new damage categories of the depletion of some minerals and of fuels and by the consideration of solid and energy damage categories till the evaluation phase.

\section{THE INVENTORY}

The plants and tools used for the mechanical processes of components and dies are not considered because they are used for a very great number of objects.

\subsection{Inventory of the components.}

Tab. 1 shows the inventory of the components and Tab.2 shows the corresponding materials, processes and waste treatments used for the LCA calculation.

\subsubsection{The MK10 model.}

- The crankshaft is built in steel 35CrMn5. The blocked part is obtained by means of forging process and is subjected to the following mechanical processes: sandblasting, heading, turning, grinding of collars and supports, drilling of 
supports and tapping of the right support. Later it is subjected to the thermal process of tempering that we have implemented in the database of code.

- The crankcase is built in aluminium alloy GD-AlSi12Cu2Fe. The blocked part is obtained by means of the casting and is subjected to milling of the upper surfaces and lapping by sandbar of the surfaces in contact of the crankshaft.

- The valve plate is built in Fe33. The blocked part is obtained by shearing from a commercial plate and its surfaces are milled and ground.

Tab.1 Inventory of the components.

\begin{tabular}{|c|c|c|c|c|}
\hline Components & Amounts & Materials used by FINI & $\begin{array}{c}\text { Weight } \\
{[\mathrm{kg}]}\end{array}$ & Processes \\
\hline \multicolumn{5}{|l|}{ MK10 model } \\
\hline $\begin{array}{l}\text { Crankshaft } \\
\text { Scrap }\end{array}$ & $\begin{array}{l}1 \\
1\end{array}$ & $\begin{array}{l}35 \mathrm{CrMn5} \\
35 \mathrm{CrMn5}\end{array}$ & $\begin{array}{l}1.450 \\
0.059\end{array}$ & $\begin{array}{l}\text { forging } \\
\text { forging } \\
\text { turning } \\
\text { grinding } \\
\text { drilling } \\
\text { threading } \\
\text { tempering }\end{array}$ \\
\hline Valve plate & 1 & $\mathrm{Fe} 33$ & 0.339 & $\begin{array}{l}\text { rolling } \\
\text { shearing } \\
\text { milling } \\
\text { grinding }\end{array}$ \\
\hline $\begin{array}{l}\text { Crankcase } \\
\text { Scrap }\end{array}$ & $\begin{array}{l}1 \\
1\end{array}$ & $\begin{array}{l}\text { GD-AlSi12Cu2Fe } \\
\text { GD-AlSi12Cu2Fe }\end{array}$ & $\begin{array}{l}0.250 \\
0.023\end{array}$ & $\begin{array}{l}\text { casting } \\
\text { casting } \\
\text { sandblasting } \\
\text { milling } \\
\text { boring } \\
\end{array}$ \\
\hline \multicolumn{5}{|l|}{ MK94 } \\
\hline $\begin{array}{l}\text { Crankshaft } \\
\text { Scrap }\end{array}$ & 1 & $\begin{array}{l}\text { GS-600 } \\
\text { GS-600 }\end{array}$ & $\begin{array}{l}1.513 \\
0.063\end{array}$ & $\begin{array}{l}\text { casting } \\
\text { sandblasting } \\
\text { turning } \\
\text { grinding } \\
\text { drilling } \\
\text { threading }\end{array}$ \\
\hline Valve plate & 1 & GD-AlSi12Cu2Fe & 0.281 & $\begin{array}{l}\text { die-casting } \\
\text { tumbling } \\
\text { milling } \\
\text { grinding } \\
\end{array}$ \\
\hline Crankcase & 1 & GD-AlSi12Cu2Fe & 0.906 & $\begin{array}{l}\text { die-casting } \\
\text { sandblasting } \\
\text { milling } \\
\text { boring }\end{array}$ \\
\hline Conveyor & 1 & polypropylene & 0.136 & injection moulding \\
\hline
\end{tabular}

Tab.2 Inventory of materials and processes used for LCA calculation.

\begin{tabular}{|c|c|c|c|c|}
\hline Components & Database materials & Database processes & Quantity & Disposal scenario \\
\hline \multicolumn{5}{|l|}{ MK10 } \\
\hline Crankshaft & 42CrMo4 I & $\begin{array}{l}\text { forging steel } \\
\text { turning steel } \\
\text { machining steel } \\
\text { hardening }\end{array}$ & $\begin{array}{l}1.509 \mathrm{~kg} \\
0.048 \mathrm{~kg} \\
0.011 \mathrm{~kg} \\
1.450 \mathrm{~kg}\end{array}$ & Recycling \\
\hline Valve plate & $\mathrm{Fe} 360 \mathrm{I}$ & $\begin{array}{l}\text { rolling } \\
\text { cutting steel } \\
\text { shares machining }\end{array}$ & $\begin{array}{l}0.339 \mathrm{~kg} \\
80 \mathrm{~cm}^{2} \\
0.089 \mathrm{~kg}\end{array}$ & Recycling \\
\hline Crankcase & G-AlSi12Cu(321) I & $\begin{array}{l}\text { cast work non-ferro } \\
\text { sandblasting } \\
\text { machining aluminium }\end{array}$ & $\begin{array}{l}0.273 \mathrm{~kg} \\
571 \mathrm{~cm}^{2} \\
0.023 \mathrm{~kg}\end{array}$ & Recycling \\
\hline \multicolumn{5}{|l|}{ MK94 } \\
\hline Crankshaft & GGG-60 & $\begin{array}{l}\text { cast work ferro } \\
\text { sandblasting } \\
\text { turning steel } \\
\text { machining steel }\end{array}$ & $\begin{array}{l}1.450 \mathrm{~kg} \\
235 \mathrm{~cm}^{2} \\
0.05 \mathrm{~kg} \\
0.013 \mathrm{~kg}\end{array}$ & Recycling \\
\hline Valve plate & G-AlSi12Cu(321) I & $\begin{array}{l}\text { die-casting } \\
\text { tumbling } \\
\text { machining aluminium }\end{array}$ & $\begin{array}{l}0.281 \mathrm{~kg} \\
283 \mathrm{~cm}^{2} \\
0.031 \mathrm{~kg}\end{array}$ & Recycling \\
\hline Crankcase & G-AlSi12Cu(321) I & die-casting & $0.918 \mathrm{~kg}$ & Recycling \\
\hline
\end{tabular}




\begin{tabular}{|l|l|l|l|l|}
\hline & & $\begin{array}{l}\text { Sandblasting } \\
\text { machining aluminium }\end{array}$ & $\begin{array}{l}745 \mathrm{~cm}^{2} \\
0.0123 \mathrm{~kg}\end{array}$ & \\
\hline Conveyor & Polypropene I & Injection moulding I & $0.136 \mathrm{~kg}$ & Incineration \\
\hline
\end{tabular}

\subsubsection{The MK94 model.}

- The crankshaft is built in GS-600. The raw part is obtained by means of the sand casting and is subjected to the same mechanical processes of the MK10 one.

- The crankcase is built in GD-AlSi12Cu2Fe. The raw part is obtained by means of the die-casting and is subjected to the same mechanical processes of the MK10 one.

- The valve plate is built in GD-AlSi12Cu2Fe. The raw part is obtained by means of the die-casting and its surfaces are milled, ground and sieved.

- The air cooled conveyor is built in polypropylene by means of injection moulding.

\subsection{Inventory of the tools.}

We have considered the die for the crankshaft, the rollers for rolling of the valve plate and the mould for the crankcase for MK10 model and the mould for the crankshaft and the dies for the valve plate and the crankcase for the MK94 model. The tools for the manufacturing of the dies are not considered (for example the tool for spark machining and the wood pattern). We have not considered the die for the conveyor for the MK94 model because it is used for many million of air cooling conveyors for different compressor type.

Tab.3 shows the inventory of the tools of the components and Tab.4 shows the corresponding materials, processes and waste treatments used for the LCA calculation.

Tab.3 Inventory of the tools of the components.

\begin{tabular}{|c|c|c|c|c|c|}
\hline 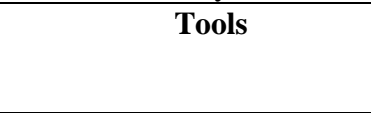 & $\mathbf{N}^{\circ}$ & $\begin{array}{c}\text { Weight } \\
{[\mathrm{kg}]}\end{array}$ & Materials & $\begin{array}{l}\text { Number of } \\
\text { components } \\
\text { produced }\end{array}$ & Processes \\
\hline \multicolumn{6}{|l|}{ MK10 } \\
\hline Die for the crankshaft & 1 & 94 & W300 & $10^{5}$ & $\begin{array}{l}\text { casting } \\
\text { milling } \\
\text { drilling } \\
\text { spark machining } \\
\text { grinding } \\
\text { hardening }\end{array}$ \\
\hline $\begin{array}{l}\text { Rollers for the rolling of the } \\
\text { valve plate }\end{array}$ & 2 & 4138 & 42CrMo4 & $10^{5}$ & $\begin{array}{l}\text { casting } \\
\text { turning } \\
\text { grinding } \\
\text { hardening and } \\
\text { tempering }\end{array}$ \\
\hline Mould for crankcase & 1 & 29 & Sand for casting & 1 & sand compression \\
\hline \multicolumn{6}{|l|}{ MK94 } \\
\hline Mould for the crankshaft & 1 & 56.25 & Sand for casting & 1 & sand compression \\
\hline Die for valve plate & 1 & 5 & W300 & $10^{5}$ & $\begin{array}{l}\text { casting } \\
\text { milling } \\
\text { drilling } \\
\text { spark machining } \\
\text { grinding } \\
\text { hardening }\end{array}$ \\
\hline Die for crankcase & 1 & 330 & W300 & $10^{5}$ & $\begin{array}{l}\text { casting } \\
\text { milling } \\
\text { drilling } \\
\text { spark machining } \\
\text { grinding } \\
\text { hardening }\end{array}$ \\
\hline
\end{tabular}

Tab.4 Inventory of materials and processes used for LCA calculation.

\begin{tabular}{|c|c|c|c|c|c|}
\hline Tools & $\begin{array}{c}\text { Materials of } \\
\text { database }\end{array}$ & $\begin{array}{c}\text { Processes of } \\
\text { database }\end{array}$ & $\begin{array}{c}\text { Weight of } \\
\text { processed } \\
\text { material } \\
{[\mathrm{kg}]}\end{array}$ & $\begin{array}{c}\text { Size } \\
{[\mathrm{mm}]}\end{array}$ & $\begin{array}{c}\text { Disposal } \\
\text { scenario of } \\
\text { database }\end{array}$ \\
\hline \multicolumn{6}{|l|}{ MK10 } \\
\hline $\begin{array}{l}\text { Die for the } \\
\text { crankshaft }\end{array}$ & S355J2G1W I & $\begin{array}{l}\text { Cast work } \\
\text { machining steel } \\
\text { EDM } \\
\text { hardening }\end{array}$ & $\begin{array}{l}94 \\
0.08 \\
1.5 \\
92.5\end{array}$ & $300 * 200 * 200$ & Recycling \\
\hline Rollers for the & 42CrMo4 I & Cast work & 4162 & $800 * 650$ & Recycling \\
\hline
\end{tabular}




\begin{tabular}{|l|l|l|l|l|l|}
\hline $\begin{array}{l}\text { rolling of the valve } \\
\text { plate }\end{array}$ & \multicolumn{2}{|l|}{$\begin{array}{l}\text { machining steel } \\
\text { hardening and } \\
\text { tempering }\end{array}$} & $\begin{array}{l}24 \\
4138\end{array}$ & \\
\hline Mould for crankcase & Sand I & & 64 & $400 * 200 * 200$ & Recycling \\
\hline MK94 & Sand I & 125 & $500 * 250 * 250$ & Recycling \\
\hline $\begin{array}{l}\text { Mould for the } \\
\text { crankshaft }\end{array}$ & S355J2G1W I & $\begin{array}{l}\text { Cast work } \\
\text { machining steel } \\
\text { EDM } \\
\text { hardening }\end{array}$ & $\begin{array}{l}5 \\
0.02 \\
0.55 \\
4.4\end{array}$ & $200 * 150 * 20$ & Recycling \\
\hline Die for valve plate & S355J2G1W I & $\begin{array}{l}\text { Cast work } \\
\text { machining } \\
\text { EDM } \\
\text { hardening }\end{array}$ & $\begin{array}{l}330 \\
1.7 \\
35 \\
293\end{array}$ & $400 * 350 * 300$ & Recycling \\
\hline Die for crankcase & & & & \\
\hline
\end{tabular}

\subsection{The new processes.}

To create the processes in which the code database is lacking we have used data obtained by literature and manufacturing concerns.

\subsubsection{The die-casting of aluminium.}

For the die-casting of aluminium alloy (die-casting 'process' pressofusione) we have considered the consumption of electric energy $E_{\mathrm{dc}}=0.02 \mathrm{kWh} / \mathrm{kg}$ and the air emissions reported in Tab.5.

Tab.5 The air emissions of die-casting (pressofusione) process.

\begin{tabular}{|l|l|}
\hline \multicolumn{1}{|c|}{ Air emission } & \multicolumn{1}{c|}{ Concentration $[\mathbf{m g} / \mathbf{k g}]$} \\
\hline Dust (coarse) & 0.62 \\
\hline $\mathrm{NO}_{2}$ & 0.86 \\
\hline $\mathrm{HCl}$ & 0.72 \\
\hline $\mathrm{HF}$ & 0.072 \\
\hline $\mathrm{CO}$ & 0.3 \\
\hline
\end{tabular}

3.3.2. The manufacturing of the dies for the die-casting and the drop-forging.

The dies for the die-casting of Aluminium and for the drop-forging of the steel are obtained by the process of spark machining (EDM). The die material for the die-casting is W300 and the one of the drop-forging is C45. In the EDM 'process' we have considered the electric energy $E_{\mathrm{ee}}=3.6 \mathrm{kWh} / \mathrm{kg}$ and a consumption of $0.1 \mathrm{~kg}$ of dielectric material (crude oil I) for $1 \mathrm{~kg}$ of removed material.

\subsubsection{The thermal treatments.}

We have represented the processes of hardening and hardening and tempering by means of the two following processes: the heating to the temperature of the processes (raising temperature) and the maintaining of this temperature for the characteristic time of the processes (maintaining temperature). The heat $\mathrm{Q}$ that must be given to the different dies is calculated to obtain the temperature $\mathrm{T}_{\mathrm{h}}=900{ }^{\circ} \mathrm{C}$ for hardening and the temperature $\mathrm{T}_{\mathrm{t}}=600{ }^{\circ} \mathrm{C}$ for tempering.

\subsubsection{The sandblasting.}

This process uses the kinetic energy produced by a compressor of power $2 \mathrm{~kW}$. We have created the 'process' sandblasting assuming that the duration of this process is $0.1 \mathrm{~min} / \mathrm{cm}^{2}$. The electric energy consumed for $1 \mathrm{~cm}^{2}$ of surface treated is: $\mathrm{E}_{\mathrm{s}}=0.0033 \mathrm{kWh}$.

\subsubsection{The tumbling.}

We have created the 'process' tumbling assuming that the electric energy consumed for $1 \mathrm{~cm}^{2}$ of surface treated is: $E_{b}=$ $0.0033 \mathrm{kWh}$.

\subsubsection{The modifications of the waste treatment recycling of non ferrous metals.}

We have replaced the 'avoided products' of the 'waste treatments' recycling aluminium and recycling non ferro with Aluminium rec I e Manganese I because the 'waste fraction' Aluminium and non ferro with these materials produce the minimum environmental gain. 


\subsubsection{The disposal scenario.}

We have assumed that the all the metallic components are recycled and the plastic ones incinerated.

3.4. Comparison between the electric energy used by two models of compressors during its life.

We assume that the two models MK10 and MK94 are used is used during 2 hours in a day, for 280 days in a year and for 10 years. The experiments have showed that the volume of the compressed air is $11 \mathrm{~m}^{3} / \mathrm{h}$ for MK10 and $11.5 \mathrm{~m}^{3} / \mathrm{h}$ for MK94. It is to be noted that the MK94 is provided with the conveyor device that decreases the temperature of the air introduced in the cylinder. This aspect allows that the volume of compressed air is greater for the MK94 model as well the two compressors have the same displacement. The energy consumed by MK94 is $\mathrm{E}_{\mathrm{MK} 94}=10080 \mathrm{kWh}$, while the energy for MK10 is $10538 \mathrm{kWh}$; therefore it is to be noted that the MK10 consumes a surplus of electric energy of 458 $\mathrm{kWh}$.

\section{LIFE CYCLE ASSESSMENT OF THE TWO FUNCTIONAL UNITS.}

\subsection{LCA by Eco-indicator 95 Europe g method.}

The Life Cycle Analysis of the two functional units is performed by SimaPro 3.1 code and Eco - indicator m1 Europe g1 method. The last method is obtained from Eco Indicator 95 dividing the weight factors of the normalisation for the year number (10) of the compressor life.

\subsubsection{LCA of conveyor of MK94 and the surplus of electric energy used by MK10.}

Fig. 2 shows the evaluation of the damages produced by the life cycle of the conveyor and by the surplus of electric energy spent by MK10 (115 mPt).

Fig. 2 The comparison between the LCA evaluation of MK10 conveyor and MK94 surplus of energy.

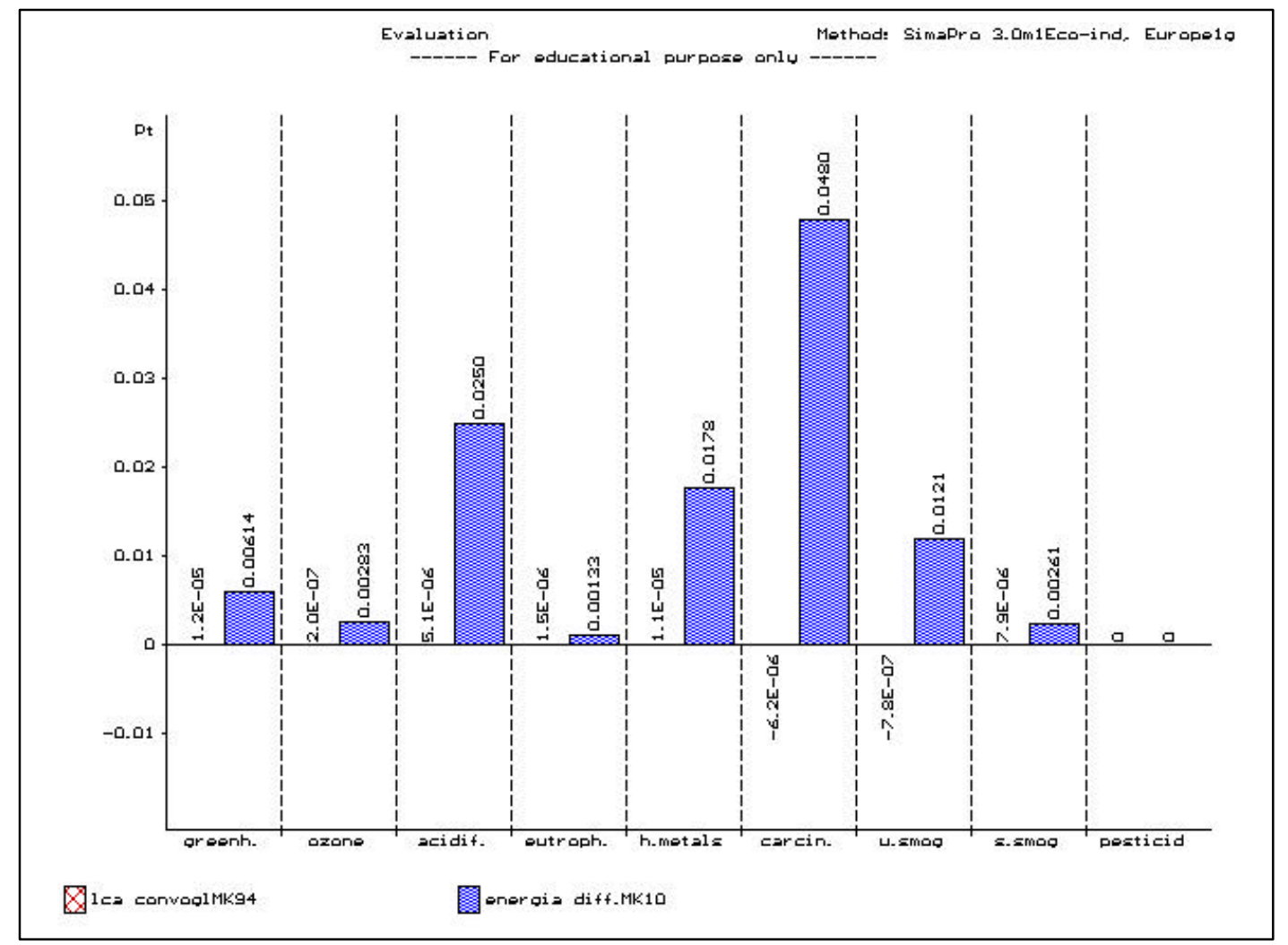

From this result we can observe that the conveyor reduces the damage due to MK10 model of $114.07 \mathrm{mPt}$ and therefore it is a choice of ecodesign.

\subsubsection{The crankshaft.}

Fig.3 shows the evaluation of the crankshafts of MK10 (2.31 mPt) and of MK94 (10.7 mPt). 
Fig.3 The evaluation of the crankshafts of MK10 and of MK94.

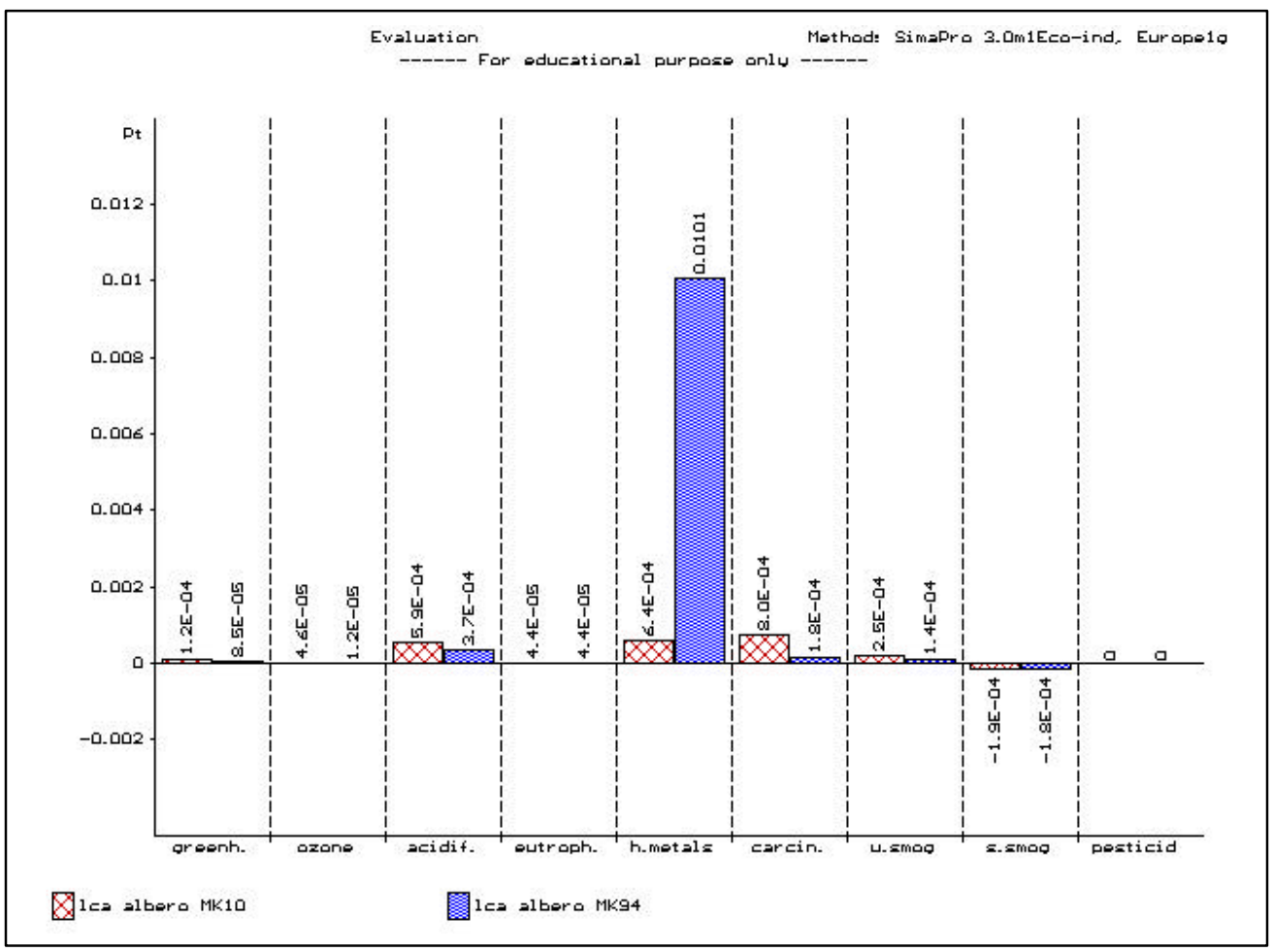

The damage produced by heavy metals for MK94 crankshaft is due principally to the casting of the steel. The damage produced by acidification and carcinogenic for MK10 crankshaft is due to the steel production and to the hardening. In this case the changing of the material is not a choice of ecodesign because the casting process (cast work) is more damaging than the forging process (forging steel)

\subsubsection{The crankcase.}

Fig. 4 shows the evaluation of the crankcases of MK10 (1.15 mPt) and of MK94 (3 mPt).

The increase of damage of MK94 crankcase is due only to the increase of its weight in respect of MK10 crankcase.

Fig.4 The evaluation of the crankcases of MK10 and of MK94.

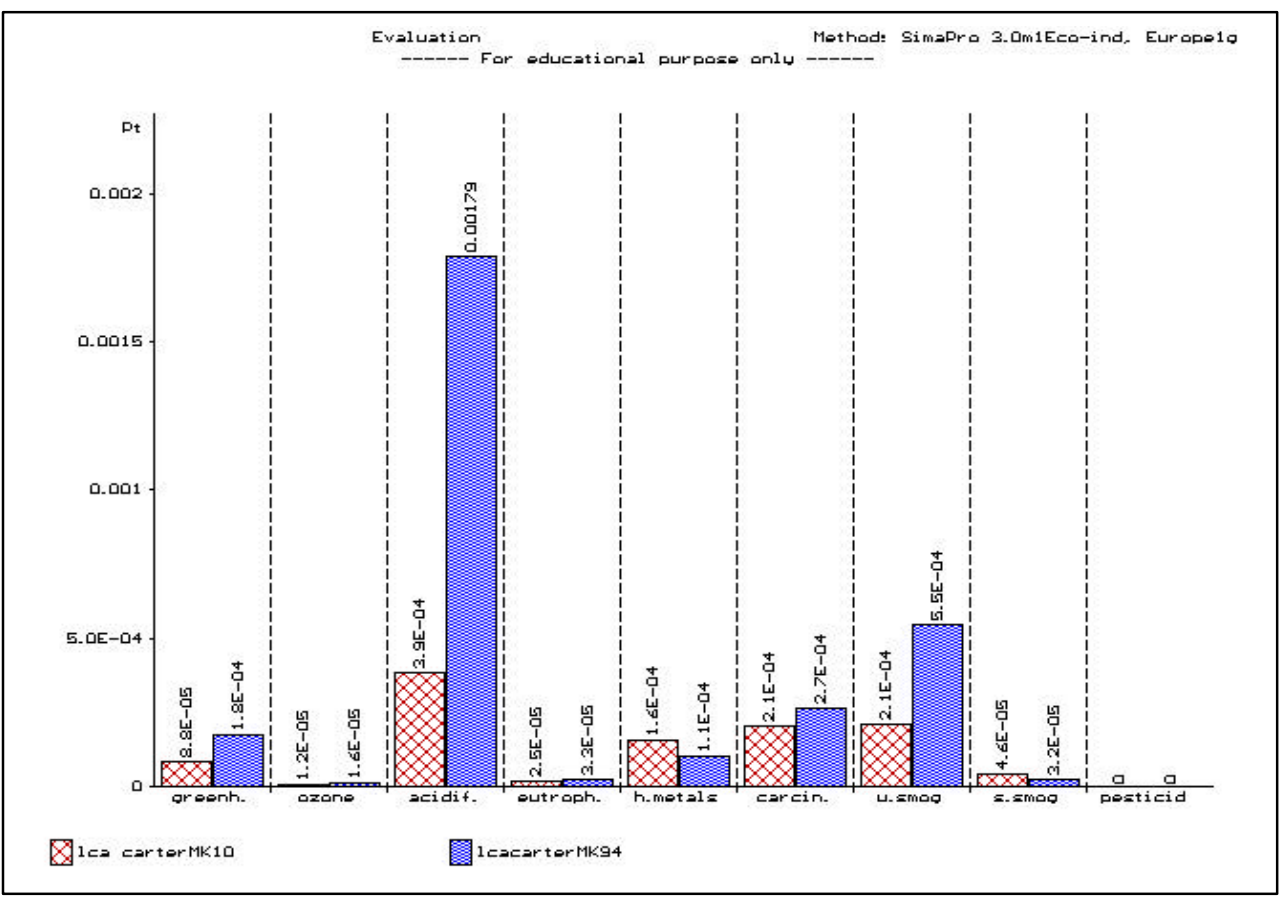

4.1.4 The valve plate

Fig.5 shows the evaluation of the valve plates of MK10 (494 $\mu \mathrm{Pt})$ and of MK94 (958 $\mu \mathrm{Pt})$. 
Even if the damage due to the tool decreases $(0.37 \mu \mathrm{Pt}$ for the die in the die-casting process of MK94 valve plate and $289 \mu \mathrm{Pt}$ for the die of MK10 valve plate), the damage of MK94 valve plate (1050 $\mu \mathrm{Pt})$ is greater than the one of MK10 valve plate $(258 \mu \mathrm{Pt})$ since the damages due to the production of material and to processes increase. Therefore the changing the material of the valve plate is not a choice of ecodesign.

Fig.5 The evaluation of the valve plates of MK10 and of MK94.

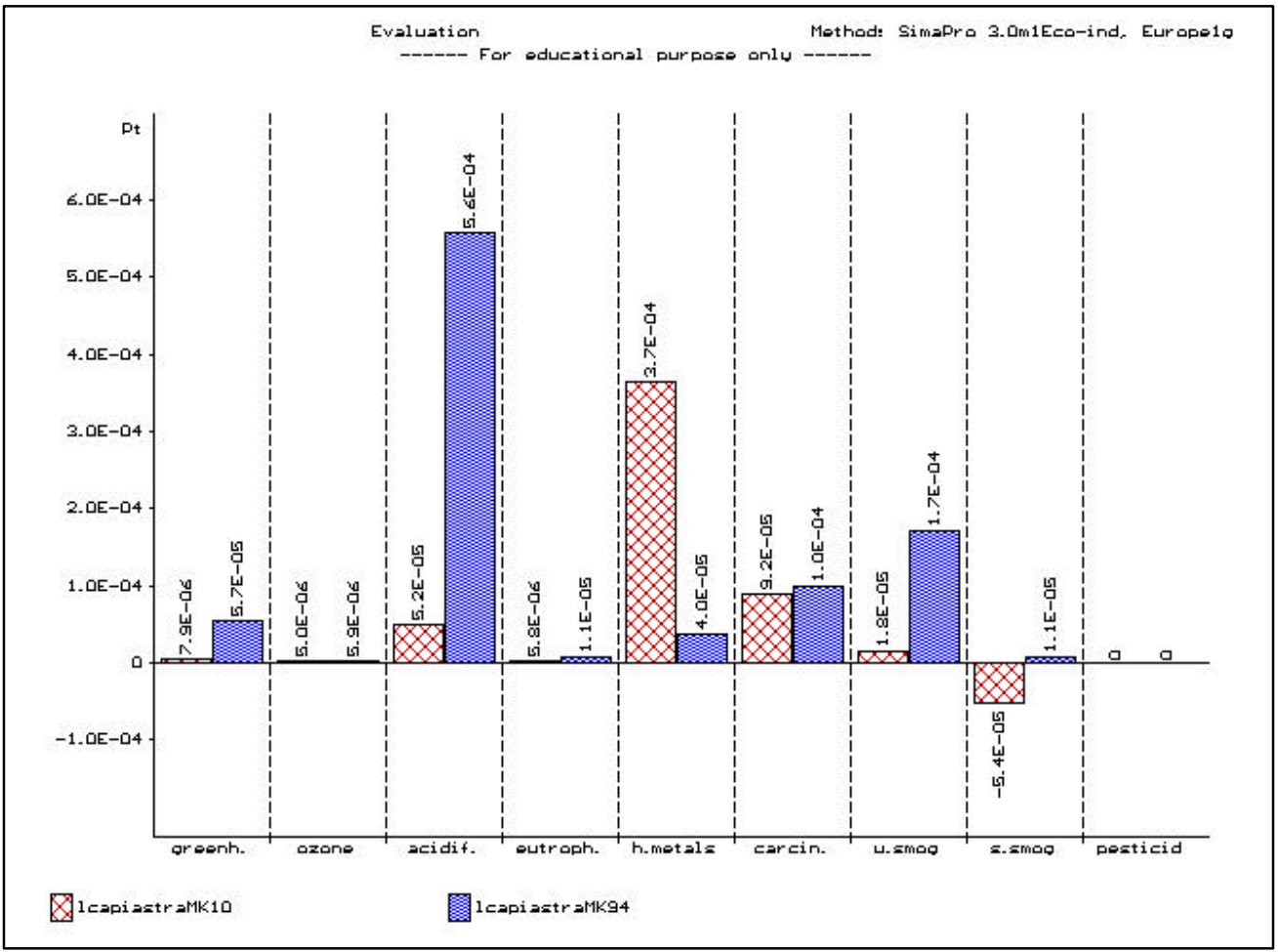

\subsubsection{Conclusions.}

Fig.6 shows the comparison of the evaluation of the two functional units of the two models of compressors.

Fig.6 The comparison between the damages of the functional units of MK10 and of MK94 models.

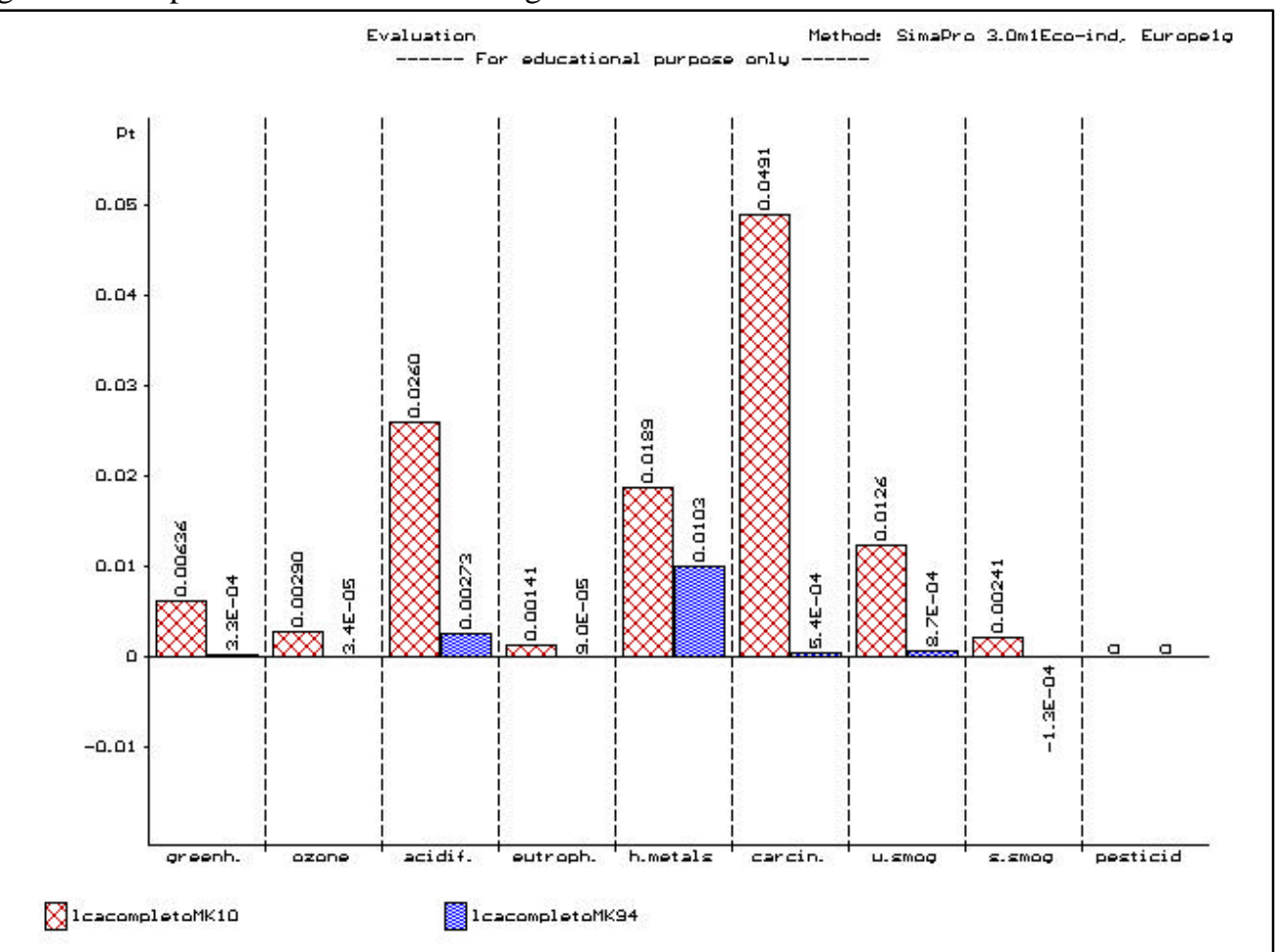


From the LCA results, we can conclude that the introduction of the conveyor reduces of $114.07 \mathrm{mPt}$ the damage produced by MK10 model; the other modifications on MK94 design increase of $11 \mathrm{mPt}$ the damage of MK10 model.

\subsection{LCA by Eco-indicator 95 Europe g modified method.}

The modifies developed in respect of the Eco-indicator 95 Europe g method are:

- we have introduced some damage categories that take into account of the depletion of some minerals and the Fossil fuels. The weight factor for the characterisation is 1 for all damage categories. For the normalisation the weight of the inventory materials is divided for the weight of the mined minerals and Fossil fuels related to each inhabitant of the world. For the evaluation the normalised weight of the inventory materials is divided for the number of the years of the duration of the reserves of minerals and Fossil fuels.

- For the solid damage category we have assumed the weight factor 0.0018 for the normalisation because we have supposed that the European produces $1.5 \mathrm{~kg}$ of waste in a day and the weight factor 1.8 for the evaluation, as in Ecopoints method.

- For the energy damage category we have assumed the weight factor 1.03 as in Ecopoints method.

- We have introduced the landrec damage category to take into account of the gain due to occupation with a landfill of a ruined land (for example a pit). For this category we have assumed for characterisation the weight factor -1 , for the normalisation 0.0018 (as the solid category) and for the evaluation 1.8 (as the solid category).

- All the weight factors for the normalisation are divided for the number of the years (10) of the compressor life.

\subsubsection{Results.}

Fig.7 shows the evaluation of LCA of the MK94 functional unit. From the results we can see that the damage increases of $5 \%$ in respect of the one obtained by the Eco-indicator 95 method, due principally to the crankcase that produces damages in the categories energy, solid, $\underline{\mathrm{Al} \text { depl and oil depl. }}$

Fig.7 The evaluation of LCA of the MK94 functional unit by new method.

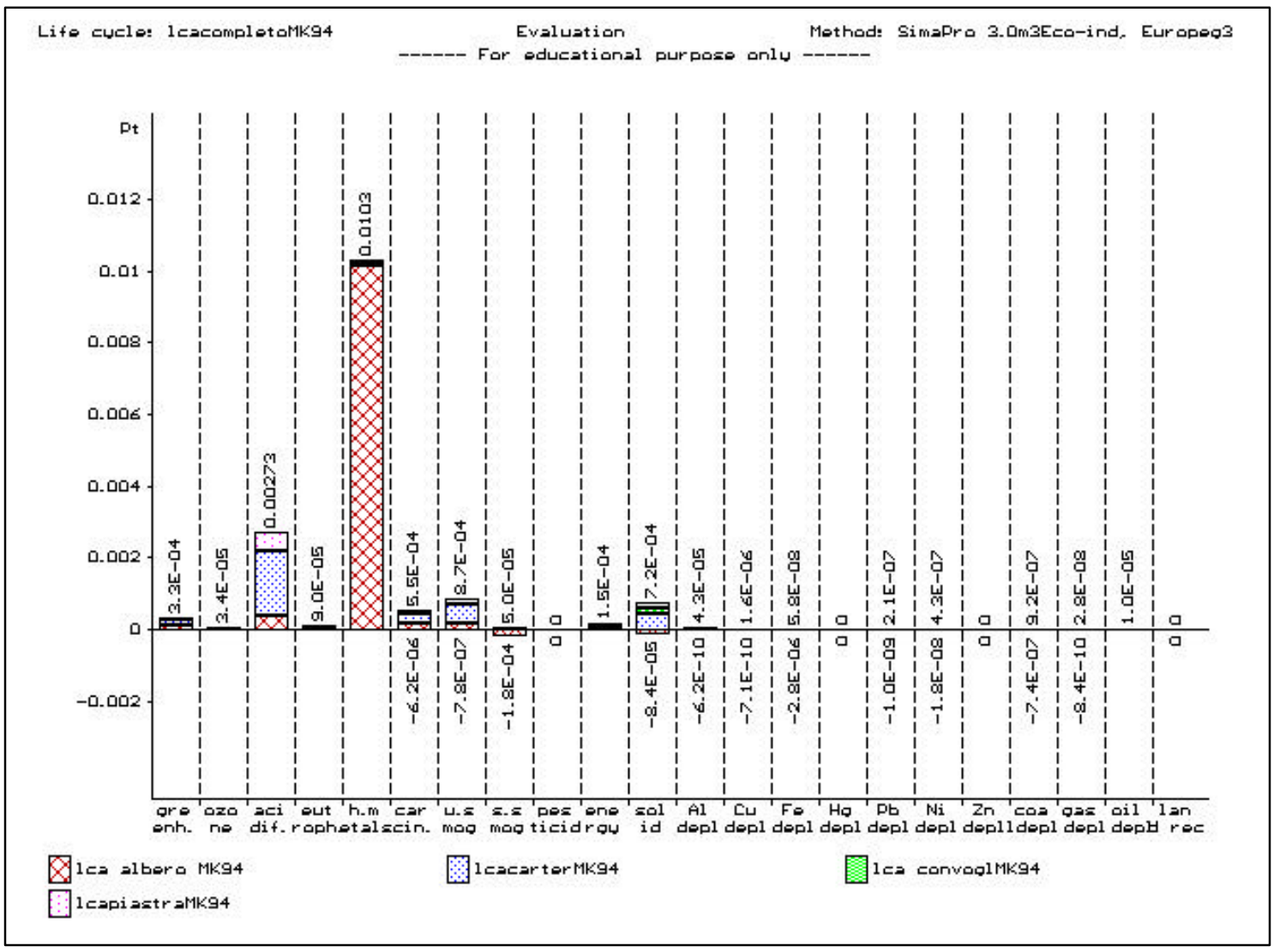

\section{SUGGESTIONS TO REDUCING THE DAMAGE DUE TO MK94 MODEL.}

\subsection{The reuse of the crankshaft and the crankcase.}

The crankshaft and the crankcase must be work for $42 * 10^{6}$ cycles. The crankshaft is subjected to an equivalent stress equal to $50 \mathrm{MPa}$ and the Niemann ${ }^{3}$ limit stress is $60 \mathrm{MPa}$. The bearing life is of $320^{*} 10^{6}$ cycles. Therefore the reuse of these components is possible and would reduce the damage from $14.7 \mathrm{mPt}$ to $1.6 \mathrm{mPt}$. 


\subsection{Design of a new ventilator.}

A decrease of the damage can be obtained by reducing the air temperature and, therefore, by increasing the volume of compressed air during each turn of the crankshaft. To decrease the temperature of the cylinder head of the MK94 compressor a ventilator with a conveyor is used. The ventilator moves the air that the conveyor drives to the head and to the valve plate. With this study we determine a new geometry of the ventilator that drives the air to the pump group directly without the conveyor.

\subsubsection{Characteristics of the new ventilator.}

The geometric characteristics remain equal to the ones of the present ventilator to do not vary the mass of ventilator that acts even as fly-wheel:

- $\quad$ number of blades $=8$

- $\quad$ external diameter $=227 \mathrm{~mm}$

- internal diameter $=100 \mathrm{~mm}$.

To determine the prevalence $\mathrm{H}$, we suppose that the ventilator gives to the air only kinetic energy. We consider a particle that at infinite distance from the impeller is at atmospheric pressure and has null velocity and in a section downstream from the impeller is at atmospheric pressure and has a meridian velocity equal to $c_{m}=10 \mathrm{~m} / \mathrm{s}^{2}$. Substituting the values in the following equation:

$\mathrm{g} * \mathrm{H}=\mathrm{c}_{\mathrm{m}}{ }^{2} / 2$

we obtain the prevalence $\mathrm{H}=5.1 \mathrm{~m}$.

From the experimental data the thermal power to dissipating results equal to: $\mathrm{P}_{\text {diss }}=600 \mathrm{~W}$.

The air temperature at the end of its compression can be calculate by the following equation:

$\mathrm{T}_{\mathrm{fe}}=\mathrm{T}_{1} * \beta^{(\mathrm{k}-1) / \mathrm{k}}$

where it is:

$\mathrm{k}=$ coefficient of the polytropic curve $=25$

$\mathrm{T}_{1}=$ the room temperature $=20^{\circ} \mathrm{C}$

$\beta=\mathrm{P}_{\mathrm{fe}} / \mathrm{P}_{1}=11$ for a safety condition.

If we substitute the values in the equation (4), we obtain: $\mathrm{T}_{\mathrm{fe}}=200^{\circ} \mathrm{C}$.

With the present ventilator and with the conveyor, the MK94 compressor rises the temperature of $120^{\circ} \mathrm{C}$ on the valve plate. Experimental tests show that to decrease the temperature of the valve plate from $200{ }^{\circ} \mathrm{C}$ to $120{ }^{\circ} \mathrm{C}$ it is necessary a flow of air of $0.12 \mathrm{~m}^{3} / \mathrm{s}$, but we assume an air flow of $0.3 \mathrm{~m}^{3} / \mathrm{s}$ that decreases further the temperature of the valve plate.

The design of the ventilator blade is obtained by a code developed by the coauthor Ing. Naldi that calculates the velocities and the geometric angles and the flow angles are determined in 11 sections of the blade. The Tab.6 shows the inputs and 1 output of the calculation and the Fig.7 some pictures of the blade.

Tab. 6 The inputs of the calculation the blade design and the outputs in the section $\mathrm{n}^{\circ} 0$.

\begin{tabular}{|c|c|}
\hline \multicolumn{2}{|l|}{ INPUT } \\
\hline Prevalence & $\mathrm{H}=5.000[\mathrm{~m}]$ \\
\hline Flow & $\mathrm{Q}=0.3000[\mathrm{~m} 3 / \mathrm{s}]$ \\
\hline Hydraulic Efficiency & eta $=0.700[-]$ \\
\hline $\begin{array}{l}\text { Speed of rotation } \\
\text { [s-1] }\end{array}$ & $\mathrm{n}=1247.000[\mathrm{giri} / \mathrm{min}] 130.586$ \\
\hline Number of blades & $Z G=8(E)$ \\
\hline \multicolumn{2}{|c|}{ CALCULATED VALUES } \\
\hline \multicolumn{2}{|c|}{ Characteristic index $n q=204.268$} \\
\hline Number of machine & $\mathrm{k}=3.860$ \\
\hline Diameter of impeller & $r \mathrm{D} 1=0.227[\mathrm{~m}]$ \\
\hline Diameter of hub & $\mathrm{d} 1=0.100[\mathrm{~m}]$ \\
\hline Diameter of shaft & d_alb $=0.000[\mathrm{~m}]$ \\
\hline Average axial speed & $\mathrm{d} c a=9.198[\mathrm{~m} / \mathrm{s}]$ \\
\hline Work done factor & $\mathrm{wdf}=0.850[-]$ \\
\hline Hydraulic work & $\mathrm{L}=82.409[\mathrm{~J} / \mathrm{kg}]$ \\
\hline$\Phi_{\mathrm{i}}$ coefficients & $\mathrm{fi}=0.621 \mathrm{psi}=0.223$ \\
\hline
\end{tabular}

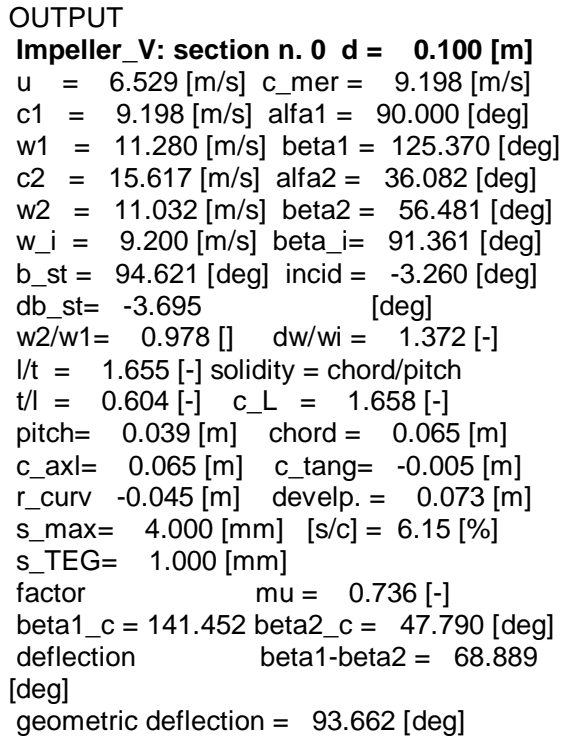


Fig.7 The geometry of the blade.
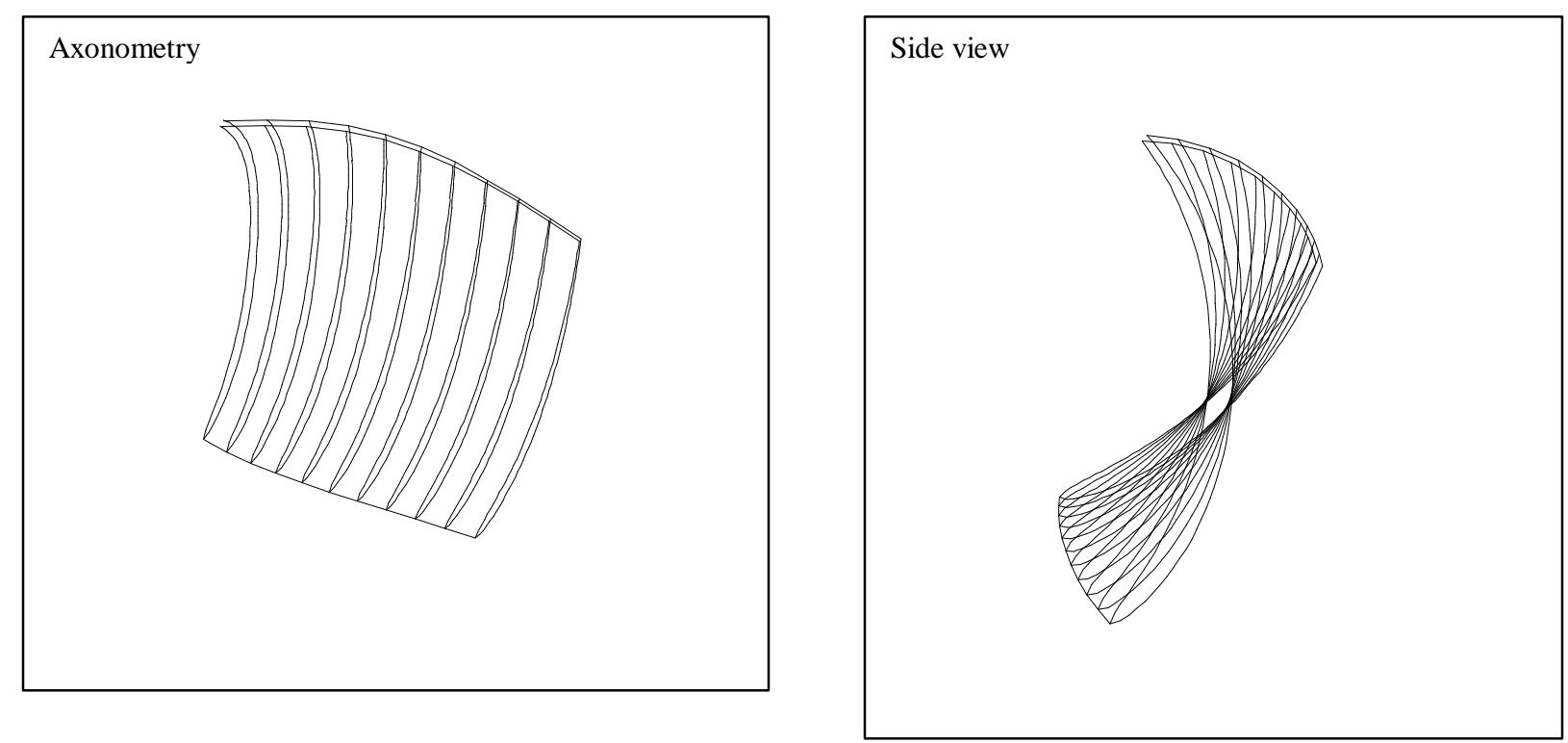

The characteristics of the blade are:

- the meridian velocity is $9.198 \mathrm{~m} / \mathrm{s}$ in all sections

- The thickness is $4 \mathrm{~mm}$ in the hub zone and $3 \mathrm{~mm}$ in the peripheral zone. Therefore the dimensions agree with the aluminium die casting process.

- The minimum thickness is $1 \mathrm{~mm}$ in the zone of air out let.

- In all sections the distance among a point of a blade and the corresponding one of the following blade is always greater than the tangential chord. Therefore there are no undercuts.

- The energy used by the ventilator to move the air without considering the mechanical losses is $82.409 \mathrm{~J} / \mathrm{kg}$, equivalent to an absorption of power of $24.7 \mathrm{~W}$.

\subsubsection{The environmental gain of the new ventilator.}

The new ventilator permits to eliminate the air cooling conveyor, so the environmental gain is equal to the damage of the conveyor $(0.03 \mathrm{mPt})$.

\section{REFERENCES}

${ }^{1}$ P. Buttol, F. Cecchini, G. Bernardi, G.Naldi, P. Neri, M. Saric, G. Tani Elementi di ecodesign nella progettazione di un compressore della Ditta FINI. Doc. ENEA OT-SBB-00010, Bologna 23/6/2000

${ }^{2}$ M. Goedkoop SimaPro 3.1. PRé Consultants, Bergstraat 6, 3811 NH Amersfoort, the Nederlands, 1995

${ }^{3}$ G. Niemann Elementi di macchine. Edizioni di Scienza e Tecnica, Milano 1983

${ }^{4}$ P. Buttol, F. Cecchini, M. Cremonini, P. Neri, E. Filippini, A. Ronchi, G. Tani LCA di un compressore di uso professionale. Doc. ENEA OT-SBB-00008, Bologna 10/12/1999 